\title{
Scale-up of the production of soy (Glycine max L.) protein films using tape casting: Formulation of film-forming suspension and drying conditions
}

\author{
Cristian Matias Ortiz ${ }^{\mathrm{a}, \mathrm{b}}$, Jaqueline Oliveira de Moraes ${ }^{\mathrm{c}}$, Ariel Roberto Vicente ${ }^{\mathrm{a}, \mathrm{b}}$, \\ João Borges Laurindo ${ }^{c}$, Adriana Noemí Mauri ${ }^{\text {a, * }}$ \\ ${ }^{a}$ Centro de Investigación y Desarrollo en Criotecnología de Alimentos (CCT La Plata, CONICET - Facultad de Ciencias Exactas-UNLP), Calle 47 esq. 116, La \\ Plata, CP 1900, Buenos Aires, Argentina \\ b Laboratorio de Investigación en Productos Agroindustriales (LIPA), Universidad Nacional de La Plata, Calle 60 y 119, La Plata, CP 1900, Buenos Aires, \\ Argentina \\ ${ }^{\mathrm{c}}$ Laboratorio de Propiedades Físicas de Alimentos (PROFI), Universidade Federal de Santa Catarina, Florianópolis, Brazil
}

\section{A R T I C L E I N F O}

\section{Article history:}

Received 23 August 2016

Received in revised form

21 December 2016

Accepted 23 December 2016

Available online 26 December 2016

\section{Keywords:}

Biodegradable materials

Soybean

Protein films

Tape casting

Drying

Formulation's effect

\begin{abstract}
A B S T R A C T
The processing variables used to produce biopolymer films may have great influence on the material's properties and production time. The aim of this work was to determine $\mathrm{i}$ ) a suitable formulation (concentration and rheological properties) for tape casting processing of soy protein suspensions ii) the effects of the drying method (heat conduction, C; and infrared radiation, IR) and temperature $(40,50$ and $60{ }^{\circ} \mathrm{C}$ ) on the drying kinetics and physical properties of resulting films. A soy protein isolate (SPI) concentration over $10.5 \% \mathrm{w} / \mathrm{v}$ was required for proper tape casting processing. Conduction drying at $60{ }^{\circ} \mathrm{C}$ $\left(C_{60}\right)$ and $I_{60}$ showed short drying times and similar drying kinetics. However, drying by $I_{60}$ yielded films having poor mechanical properties. Raising the drying temperature increased film's tensile strength, Young's modulus, glass transition temperature ( $\mathrm{Tg}$ ), and heat seal strength. The results of this study demonstrated that it is possible to produce soy protein films at large scale by tape casting. The influence of the processing method and drying conditions on soy protein film properties are discussed.
\end{abstract} (C) 2016 Elsevier Ltd. All rights reserved.

\section{Introduction}

In the last decade, great efforts have been devoted to develop biodegradable materials derived from biopolymers of agricultural origin (Guilbert \& Cuq, 2005) such as proteins. The properties of protein films have been shown to be strongly dependent on the conditions used throughout the production process (Denavi, PerezMateos, Añón, Montero, Mauri, \& Gómez-Guillén, 2009; Denavi, Tapia-Blácido, Añón, Sobral, Mauri, \& Menegalli, 2009; Foulk \& Bunn, 2001; Lafargue, Lourdin, \& Doublier, 2007; Tapia-Blácido, Sobral, \& Menegalli, 2005). Small protein-based films $(1-30 \mathrm{~cm})$ are usually obtained in laboratory by casting. In this method a colloidal dispersion made up of the protein, a solvent and, frequently, a plasticizer is poured on an appropriate support. Afterwards, the suspension is commonly dried in convection ovens

\footnotetext{
* Corresponding author.

E-mail address: anmauri@quimica.unlp.edu.ar (A.N. Mauri).
}

for relatively long times (e.g. 6-12 h). The film thickness is controlled by the mass of dispersion poured onto the support.

Tape casting is an upgrading of the casting method and has been widely used in paper, plastic, ceramics and paint industries (Cuq, Gontard, \& Guilbert, 1998; Richard \& Twiname, 2000, p. 293). In recent years it has been suggested as a suitable approach to scaleup biodegradable films, which can be negatively affected by some drying strategies (Moraes, Scheibe, Sereno, \& Laurindo, 2013). This technique consists in spreading the film-forming suspension on a support with a doctor blade device, which allows controlling the suspension thickness. After that, the spread suspension is dried at a controlled temperature (Moraes, Scheibe, Augusto, Carciofi, \& Laurindo, 2015; Moraes et al., 2013; Tanimoto, Hayakawa, \& Nemoto, 2005). The heat supply during the drying step can be done by heat conduction, convection, infrared radiation, or by a combination of these mechanisms. Tape casting processing, requires film-formation suspensions with shear-thinning behavior and a low viscosity at the shear rates (to ensure appropriate flow conditions under the blade) and high viscosity at low-shear stresses 
(to minimize undesired flow and sedimentation) (Moraes et al., 2013). Consequently, determining the concentration of each component used to obtain the film-forming suspension is fundamental to achieve the rheological-desired behavior.

Whereas several studies have determined the effects of film formulation on the properties of the resulting materials (Condés, Añón, Mauri, \& Dufresne, 2015; Han, Shin, Park, \& Kim, 2015; Ramos, Fernandes, Silva, Pintado, \& Malcata, 2012) only few have focused on the influence of the drying process itself. Moreover, the influence of the drying temperature on the film properties depends on the characteristics of the film-forming suspension, such as preexisting gel phase or the tendency to thermal gelation during drying. Several phenomena may occur throughout drying such as the transition from a rubbery to a vitreous phase, phase separation or crystallization (Wittaya, 2012). High drying temperatures may lead to protein restructuring, greatly affecting the properties of the resulting films (Mauri \& Añón, 2012). In addition, high evaporation rates may produce non-cohesive films, affecting the forming of protein structures because of denaturation (Guilbert \& Cuq, 2005). Most published researches conducted to date have only focused on convective drying treatments (Moraes, Reszka, \& Laurindo, 2014; Moreira et al., 2011; Reis et al., 2013; Tapia-Blácido, do Amaral Sobral, \& Menegalli, 2013). The information available on conductive and infrared radiation drying biopolymer films is very limited (Moraes et al., 2015). The heat transfer from the hot surface to the drying suspension, together with the flow pattern of the carrying air over the suspension control the material drying rate. A detailed discussion of this problem is given by Zotarelli, Carciofi, and Laurindo (2015). So heat transfer by conduction or IR radiation to film forming suspension during tape casting manufacture of protein films may affect protein conformation and the way protein chains could interact each other, conditioning the physicochemical properties of the resulting materials.

The aim of this work was to determine adequate process conditions for producing soy protein films by tape casting, as well as the influence of the drying method (heat conduction and IR) and also drying temperature on the physical properties of the resulting films.

\section{Materials and methods}

\subsection{Materials}

A commercial soy protein isolate (SPI) SUPRO 500E, kindly supplied by DuPont $\mathrm{N} \& \mathrm{H}$ (Brazil) was used as raw material. The protein content of SPI, as measured by the Kjeldahl method, was $85 \pm 2 \%(\mathrm{w} / \mathrm{w}$ on dry basis; $\mathrm{N} \times 5.71)$; being ashes (2.4\%), lipids $(\leq 1 \%)$, and carbohydrates ( $\cong 11 \%$ ) the other present components. And protein solubility (Bradford, 1976) of SPI was $39.5 \pm 2.8 \%$.

Glycerol (p.a. Anedra) was used as a plasticizer in all the experiments.

\subsection{Formulation and process variables}

\subsubsection{Rheological measurements of film forming suspensions}

The apparent viscosity ( $\eta_{\mathrm{app}}$ ) and flow behavior of film forming suspensions prepared with different SPI concentrations (5.0, 10.0, $10.5,11.0$ and $12.5 \mathrm{~g}$ per $100 \mathrm{~mL}$ of suspension $)$ and glycerol $(0.3 \mathrm{~g} / \mathrm{g}$ pf SPI) were evaluated in a ReoStress 600 rheometer (Thermo Haake, Karlsruhe, Germany) using a $1 \mathrm{~mm}$ gap parallel-plate serrated sensor. The SPI suspensions were maintained at $20^{\circ} \mathrm{C}$ by a jacketed thermostatic system connected to a circulating water bath (Circulator DC50 Thermo Haake, Karlsruhe, Germany). The shear rate (D) was increased from 0 to $500 \mathrm{~s}^{-1}$ in 2 min, maintained for $1 \mathrm{~min}$ and then decreased to $0 \mathrm{~s}^{-1}$ in $2 \mathrm{~min}$. The $\eta_{\text {app }}$ was calculated in the ascending curves at $9 \mathrm{~s}^{-1}$ which was the strain rate applied in the tape casting equipment under working conditions. It was calculated based on the suspension application speed $\left(1.8 \mathrm{~cm} \mathrm{~s}^{-1}\right.$ ) and doctor blade gap (thickness of $2 \mathrm{~mm}$ ) (Steffe, 1996). The flow $(\mathrm{n})$ and consistency indices $(K)$ were determined after adjusting the empirical data according to the Ostwald de Waele rheological model (aka the Power-Law model),

$\tau=K D^{n}$

in which $\tau$ is the shear stress (Pa), $K$ the consistency index (Pa ${ }^{n}$ ), and $n$ is the flow-behavior index.

\subsubsection{Selection of protein concentration}

Soy protein films were prepared by tape casting with filmforming suspensions containing 5.0, 10.0, 10.5, 11.0 and $12.5 \mathrm{~g}$ SPI per $100 \mathrm{~mL}$ of suspension and $0.3 \mathrm{~g}$ glycerol $/ \mathrm{g}$ SPI at $\mathrm{pH} 10.5$. The film-forming suspensions were degassed under vacuum ( $2 \mathrm{~min}$ at $400 \mathrm{~mm} \mathrm{Hg}$ ) and immediately spread at a speed of $1.8 \mathrm{~cm} \mathrm{~s}^{-1}$ onto a $30 \mathrm{~cm} \times 84 \mathrm{~cm}$ Plexiglas ${ }^{\mathbb{R}}$ plate, covered with a polyester film $\left(\right.$ Mylar $^{\circledR}$, DuPont, Brazil) to facilitate film removal after drying. A spreading system with a thickness control device (doctor blade BYK, Shanghai, China) (Fig. 1A) was used to spread the film-forming suspension on the tape casting support using a predefined thickness $(2 \mathrm{~mm})$. The Plexiglas ${ }^{\circledR}$ plate was heated at $60{ }^{\circ} \mathrm{C}$ by a water circulating system through an internal coil.

\subsubsection{Drying conditions}

Once the most appropriate protein concentration was selected, a set of films were prepared as described previously. The drying step was performed under the following conditions: i) $40{ }^{\circ} \mathrm{C}$, ii) $50{ }^{\circ} \mathrm{C}$ and iii) $60{ }^{\circ} \mathrm{C}\left(\mathrm{C}_{40}, \mathrm{C}_{50}, \mathrm{C}_{60}\right.$, respectively) and iv $)$ infrared radiation at approximately $60{ }^{\circ} \mathrm{C}\left(\mathrm{IR}_{60}\right)$ (Table 1$)$. A workbench with eight infrared lamps (Philips, 150 Watt per lamp), $40 \mathrm{~cm}$ above the film surface, was used as source of infrared radiation (Fig. 1B). Heat flux transducers were used to verify the infrared heat fluxes on the suspensions surfaces during drying, resulting in $42.3 \mathrm{~W} \mathrm{~m}^{-2}$ for $200 \mathrm{~V}$. The film temperature was monitored with an IR thermometer (Testo 845, Lenzkirch, German). After drying the films, they were conditioned for $48 \mathrm{~h}$ at $20^{\circ} \mathrm{C}$ and $58 \%$ relative humidity (RH), in desiccators containing $\mathrm{NaBr}$ saturated solutions, prior to being characterized.

\subsubsection{Drying kinetics}

The drying curves were obtained according to Moraes et al. (2015) by measuring the mass loss during drying. The weighing system consisted of an aluminum plate $(15 \mathrm{~cm} \times 15 \mathrm{~cm})$ with an internal electrical resistance controlled by a PID temperature controller. The plate had a Mylar ${ }^{\circledR}$ film (thickness $250 \mu \mathrm{m}$ ) on its upper surface and placed on a semi-analytical scale (AS2000C, Brazil). The initial suspension thickness was adjusted to $2 \mathrm{~mm}$. Weigh was recorded every 5 min during. During drying the suspension temperature was measured with three thermocouples inserted into the suspension and coupled to a data acquisition system (Benchlink Data Logger 3, Agilent, USA). The spatial temperature distribution on the film surface during drying was monitored using an infrared camera (FLIR 360, Danderyd, Sweden). Film drying rates were determined using Equation (2):

$R=\frac{\Delta x}{\Delta t}=\frac{X_{t}-X_{t+\Delta t}}{\Delta t}$

being $R$ is the drying rate, $X t$ and $X t+\Delta t$ are the moisture contents at times $t$ and $t+\Delta t$, respectively. The experiments were done at least in duplicate. 


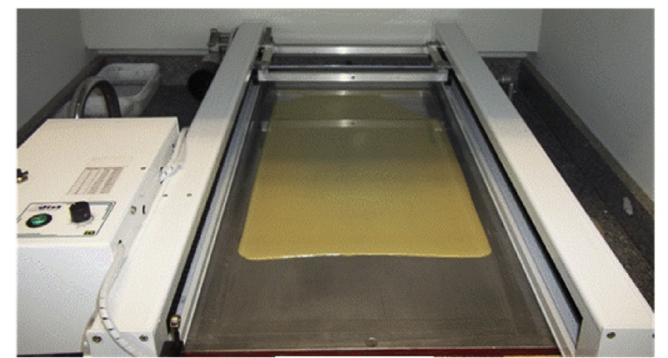

A

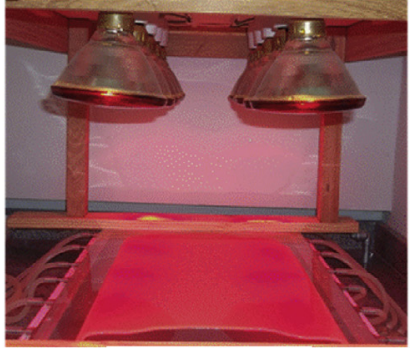

B

Fig. 1. Tape casting equipment used for conduction drying (A) and IR radiation drying (B).

Table 1

Nomenclature of the different drying process studied in this manuscript to obtain soy protein films by tape casting.

\begin{tabular}{lll}
\hline Sample & Drying technology & Drying temperature $\left({ }^{\circ} \mathrm{C}\right)$ \\
\hline $\mathrm{C} 40$ & Conduction & 40 \\
$\mathrm{C} 50$ & Conduction & 50 \\
$\mathrm{C}_{60}$ & Conduction & 60 \\
$\mathrm{IR}_{60}$ & Infrared light & 60 \\
\hline
\end{tabular}

\subsection{Films characterization}

\subsubsection{Thickness}

Film thicknesses were measured with a digital coating thickness gauge (Check Line DCN-900, USA). Ten measurements were done for each drying condition evaluated.

\subsubsection{Color}

Color was determined with a Minolta Chromameter (CR 300, Minolta Chroma Co., Osaka, Japan) by placing the films on the surface of the white standard plate (color coordinates of $L_{\text {stan- }}$ dard $97.3, a_{\text {stantard }}=0.14$ and $\left.b_{\text {standard }}=1.71\right)$. The instrument was standardized by means of a set of three Minolta calibration plates. A CIE Lab color scale was used to measure the degree of lightness $(L)$, redness $(+a)$ or greenness $(-a)$, and yellowness $(+b)$ or blueness $(-b)$ of the films. The total color difference $(\Delta E)$ was calculated using Equation (3):

$\Delta E=\sqrt{\left(L_{\text {film }}-L_{\text {standard }}\right)^{2}+\left(a_{\text {film }}-a_{\text {standard }}\right)^{2}+\left(b_{\text {film }}-b_{\text {standard }}\right)^{2}}$

For each drying condition tested, nine measurements were done on different regions of the films and averaged. Three films were evaluated per each drying condition.

\subsubsection{Opacity}

Each film specimen was cut into a rectangular piece $(0.5 \mathrm{~cm} \times 2 \mathrm{~cm})$ and placed inside of the UV-vis spectrophotometer (Beckman DU650, Germany) at $500 \mathrm{~nm}$. Air was used as reference for transparency measurements. The opacity of the films was calculated from the absorbance at $600 \mathrm{~nm}$ divided by the film's thickness $(\mathrm{mm})$ Measurements were performed in triplicate.

\subsubsection{Moisture content (MC)}

The films were weighed and dried in an oven at $105{ }^{\circ} \mathrm{C}$ until constant weight. MC was determined in triplicate for each drying condition and calculated as the percentage of weight loss relative to the initial weight (ASTM D644-94, 1994). Measurements were done in triplicate.

\subsubsection{Solubility}

Film solubility was determined in triplicate, according to Gontard, Guilbert, and Cuq (1992). Three film pieces $(2 \mathrm{~cm}$ in diameter) were immersed in $50 \mathrm{~mL}$ distilled water at $22-25{ }^{\circ} \mathrm{C}$ and stirred for $24 \mathrm{~h}$. After filtration, the insoluble material was taken and dried in a forced-air oven $\left(105{ }^{\circ} \mathrm{C}\right.$ for $24 \mathrm{~h}$ ). Results were expressed in \% and the measurements were done in triplicate.

\subsubsection{Water-vapor permeability (WVP)}

WVP tests were based on the ASTM method E96-80 (1989) with minor modifications (Gennadios, Weller, \& Gooding, 1994). Films were put over a circular opening of $0.00185 \mathrm{~m}^{2}$ in a permeation cell and stored at $20^{\circ} \mathrm{C}$ in a desiccator. To maintain a $75 \% \mathrm{RH}$ gradient across the film, anhydrous silica $\left(0 \% \mathrm{RH}_{\mathrm{c}}\right)$ was placed inside the cell and a saturated $\mathrm{NaCl}$ solution $(75 \% \mathrm{RH})$ in the desiccator. Watervapor transport was determined from the weight gain of the permeation cell. After reaching steady-state conditions changes in the cell weight were recorded and plotted as a function of time. The results were represented by a straight line and calculated by linear regression (OriginPro8.5 software). The water vapor transmission rate was calculated from the slope of the straight line $\left(\mathrm{g} \mathrm{H}_{2} \mathrm{O} \mathrm{s}^{-1}\right)$ divided by the cell area $\left(\mathrm{m}^{2}\right)$. WVP $\left(\mathrm{g} \mathrm{H}_{2} \mathrm{O} / \mathrm{Pa} \mathrm{s} \mathrm{m}\right)$ was calculated from Equation (4):

$W V P=\frac{W V T R}{P_{v}^{H 2 O}\left(R H_{d}-R H_{c}\right) A} d$

in which $W V T R=$ the water-vapor-transmission rate, $P_{v}^{H 2 O}=$ vapor pressure of water $(1753.35 \mathrm{~Pa})$ at the test temperature $\left(20^{\circ} \mathrm{C}\right)$, $R H_{d}=\mathrm{RH}$ in the desiccator, $R H_{c}=\mathrm{RH}$ in the permeation cell, $A=$ permeation area, and $d=$ film thickness $(\mathrm{m})$. Measurements were done in triplicate for each drying condition.

\subsubsection{Glass transition temperature}

The glass-transition temperature $(\mathrm{Tg})$ of the films was determined by differential scanning calorimetry using a DSC TA2010 calorimeter Model Q100 V9.8 Build296 (TA Instrument, New Castle, DE, USA) equipped with a TA5000 temperature controller and a quench-cooling accessory. Temperature and heat-flow calibrations were carried out according to ASTM indications, with lauric acid, stearic acid, and indium as standards. Hermetically sealed aluminum pans containing $10-15 \mathrm{mg}$ of sample were scanned at $10^{\circ} \mathrm{C} \mathrm{min}^{-1}$ over the range -100 to $220^{\circ} \mathrm{C}$. The $\mathrm{T} g$ was considered to be the inflexion point of the base line caused by the discontinuity of the specific heat of the sample and was calculated by means of the Universal Analysis V4.2E software (TA Instruments, New Castle, DE, USA). All the assays were performed at least in duplicate. 


\subsubsection{Contact angle}

Surface hydrophobicity was assessed by measuring the contact angle at room temperature, using a goniometer (Ramé-Hart Model 250 , Succasunna, USA). A $5 \mu \mathrm{L}$ drop of demineralized water was placed on the surface of the film using an automatic piston syringe and photographed. An image analyzer (DROPimage Advanced v2.2) was used to measure the angle formed between the surface of the film and the drop of water. For each film, the hydrophobicity was obtained from the values of initial contact angle (average value of contact angles measured on both sides of the drop). Ten measurements were done on different areas of the film surface and averaged. Five film samples were measured for each drying condition tested.

\subsubsection{Mechanical properties}

Film mechanical properties were determined by performing tensile tests according to the ASTM D882-02 norm (ASTM, 2004), in a texture analyzer TA.XT2i (Stable Micro Systems, Surrey, England). The films were cut into strips, $(6 \mathrm{~mm} \times 80 \mathrm{~mm})$ and mounted between two grips at opposite ends. Grip separation was $50 \mathrm{~mm}$ and the crosshead speed was $0.5 \mathrm{~mm} \mathrm{~s}^{-1}$. The tensile strength and the elongation at break were determined directly from the stressstrain curves using Texture Expert V.1.15 software (Stable Micro Systems, Surrey, England). The Young's modulus (E) was calculated from the initial slope of the curve. At least six measurements were done for each drying condition tested.

\subsubsection{Heat seal strength}

Heat seal strength was measured according to ASTM F88-00 (2004). Two film stripes $(76 \mathrm{~mm} \times 25 \mathrm{~mm})$ were cut and thermo-sealed on a hot wire-sealing machine (Lipari CC400, Argentina). The thermo seal strength was evaluated in a texturometer (TA.XT2i, Stable Micro Systems, England). The samples were attached on both ends sides of the seal area with two grips and subjected to a tensile test. The force $(\mathrm{N})$ required for thermo-seal failure was recorded. The stripes were visually inspected to determine the nature of the failure (adhesive, cohesive or delamination), according to ASTM F88-00 (2004). Five samples were evaluated for each drying condition tested.

\subsection{Statistical analysis}

Experimental results were expressed as mean \pm standard deviation and subjected to analysis of variance (ANOVA). Means were compared on the Tukey's least significant difference test, at a significance level of $\alpha=0.05$, using the SYSTAT v. 12 software (Systat Software, Inc., Chicago, USA).

\section{Results and discussion}

\subsection{Characterization of the soy protein suspensions}

This study was done with a commercial soy protein isolate, in which all proteins were denatured (Supplementary Fig. 1) as depicted from the lack of the typical denaturation DSC thermogram endotherms corresponding to the two main protein fractions: $\beta$ conglicinin (7S) and glicinin (11S) in native SPI, according to Denavi \& Perez-Mateos et al., 2009; Denavi \& Tapia-Blácido et al., 2009. The rheological behavior of the suspensions containing different protein concentrations was evaluated to find the most appropriate formulation to produce films by tape casting, as shown in Fig. 2 and Table 2. The experimental values for shear stress as a function of the shear rate were properly fitted by the Ostwald de Waele model $\left(\mathrm{R}^{2} \geq 0.997\right)$. The SPI suspensions exhibited a shear-thinning behavior $(K>0 ; 0<n<1)$, their apparent viscosities values

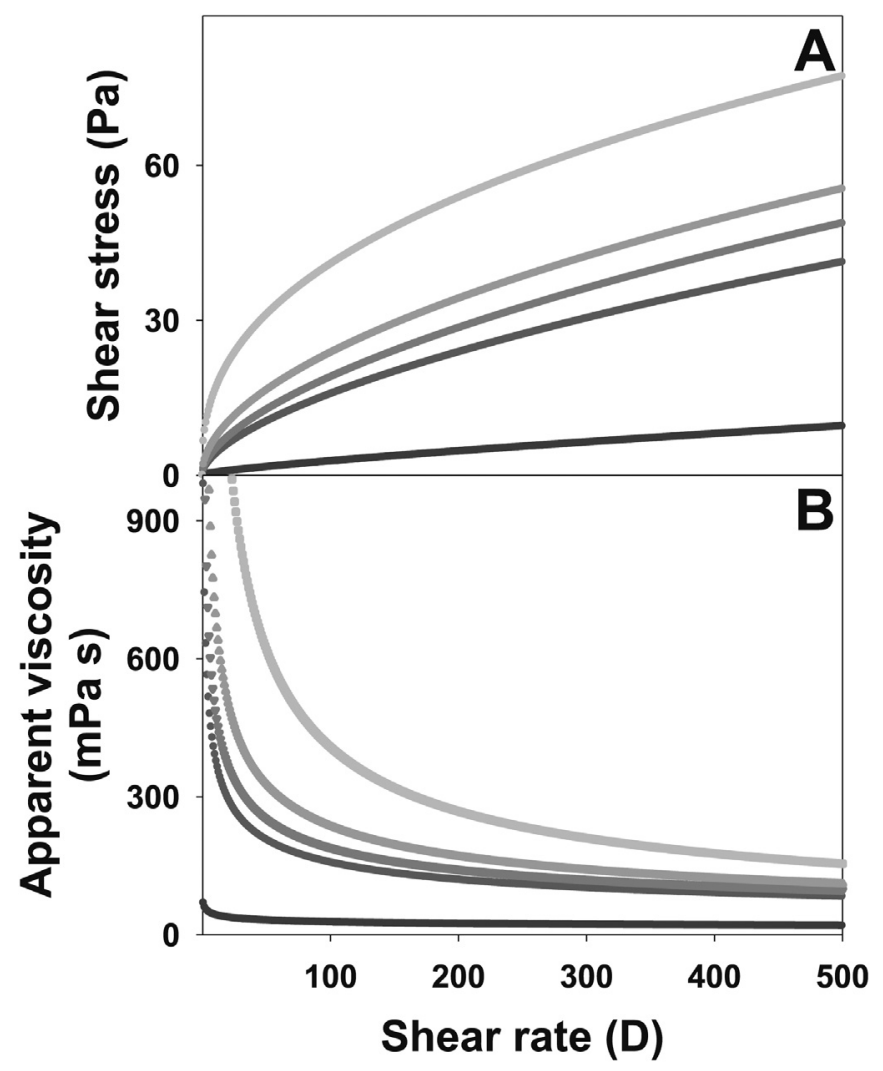

Fig. 2. Shear stress (Pa) (A) and apparent viscosity (mPa s) (B) vs. shear rate (D) of filmogenic suspensions containing different concentrations of SPI ((๑) 5.0, (๑) 10.0, (๑) 10.5 , (०) 11.0 and (०) $12.5 \%(\mathrm{~m} / \mathrm{v}))$.

decreased as the strain rate gradient increased. This pseudoplastic behavior of the suspensions became progressively pronounced at higher protein content. Flow-behavior index $(n)$ decreased and $K$ parameter increased with increasing SPI concentration. As expected, higher protein concentration lead to higher apparent viscosity. As mentioned before, shear-thinning behavior is adequate for to the production of films by tape casting (Moraes et al., 2013).

Previous studies have usually generated soy protein films by casting by using suspensions containing $5 \% \mathrm{w} / \mathrm{v}$ protein SPI (Denavi \& Perez-Mateos et al., 2009; Denavi \& Tapia-Blácido et al., 2009; Echeverria, Eisenberg, \& Mauri, 2014; Mauri \& Añón, 2006, 2008; Salgado, Fernández, Drago, \& Mauri, 2011; Salgado, Molina Ortiz, Petruccelli, \& Mauri, 2010). This level was not adequate for the tape casting process tested herein because the suspension flowed off before the spreading step. Only at higher protein concentration $(\geq 10.5 \% \mathrm{w} / \mathrm{v}$ of $\mathrm{SPI}$ ) the film forming suspension showed an adequate flow properties for pouring and spreading on the tape casting support. A second set of experiments showed that was not possible to obtain homogeneous films at SPI concentrations higher than $10.5 \%$ due to incomplete degassing which, resulted in the presence of bubbles in the films. Thus, suspensions containing 10.5\% SPI, exhibiting adequate viscosities and could be spread properly on the tape casting support and yielded films with no bubbles were selected to evaluate the influence of drying conditions on the physical properties of tape casting soy protein films. The blade gap was fixed at $2 \mathrm{~mm}$ and operated at a shear rate $c a .9$ $\mathrm{s}^{-1}$ (Table 2). 
Table 2

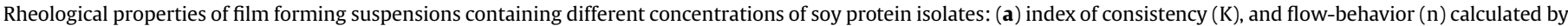
the Ostwald de Waele model; (b) Apparent viscosity values at $9 \mathrm{~s}^{-1}$ shear rate (D).

\begin{tabular}{|c|c|c|c|c|}
\hline \multirow[t]{2}{*}{$\mathrm{g} \mathrm{SPI} / 100 \mathrm{~mL}$} & \multicolumn{3}{|c|}{ a. Parameters of Ostwald de Waele model } & \multirow{2}{*}{$\begin{array}{l}\text { b. Apparent viscosity (mPa s) } \\
\mathrm{D}=9 \mathrm{~s}^{-1}\end{array}$} \\
\hline & $\mathrm{K}\left(\mathrm{Pa} \mathrm{s}^{\mathrm{n}}\right)$ & $\mathrm{N}$ & $\mathrm{r}^{2}$ & \\
\hline 5.0 & $0.068 \pm 0.010 \mathrm{c}$ & $0.792 \pm 0.012 \mathbf{a}$ & 0.999 & $53.7 \pm 2.7 \mathbf{e}$ \\
\hline 10.0 & $0.979 \pm 0.038 \mathbf{b c}$ & $0.602 \pm 0.008 \mathbf{b}$ & 0.999 & $393.4 \pm 6.1 \mathbf{d}$ \\
\hline 10.5 & $1.260 \pm 0.196 \mathbf{b c}$ & $0.588 \pm 0.012 \mathbf{b}$ & 0.999 & $510.4 \pm 57.2$ c \\
\hline 11.0 & $2.062 \pm 0.267 \mathbf{b}$ & $0.530 \pm 0.018 \mathrm{c}$ & 0.999 & $740.6 \pm 53.7 \mathbf{b}$ \\
\hline 12.5 & $6.568 \pm 1.118 \mathbf{a}$ & $0.396 \pm 0.025 \mathbf{d}$ & 0.997 & $2232.2 \pm 117.7 \mathbf{a}$ \\
\hline
\end{tabular}

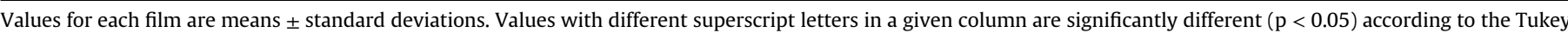
test.
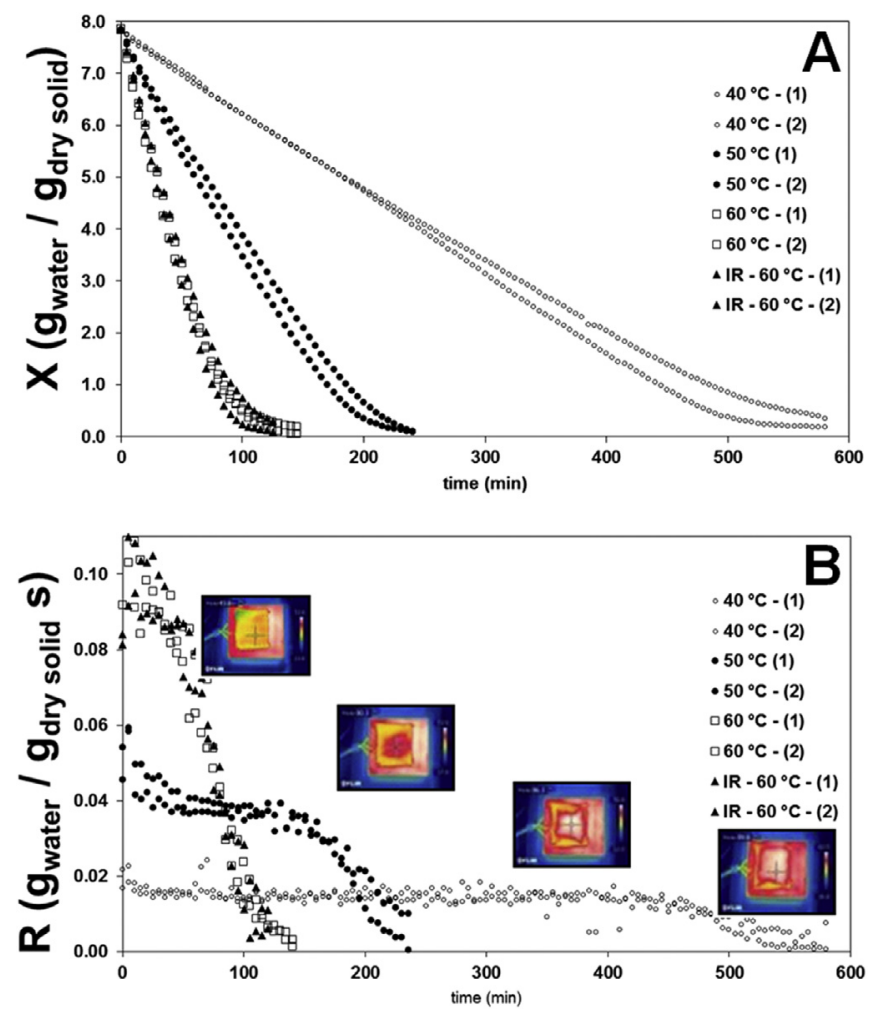

Fig. 3. Drying curves of SPI films using different temperatures and methods (A); drying rates $(\mathbf{B})$. All represented in duplicate.

\subsection{Drying kinetics}

The drying curves of soy protein films for $C_{40}, C_{50}, C_{60}$, and $I_{60}$ are shown in Fig. 3. The thermographs showed in Fig. 3a pointed out that the temperature of the film was homogeneous until the late stages of drying. The drying processes showed a short initial period of temperature adaptation, a constant rate period and a falling rate period (Moraes et al., 2015). The constant drying rate was $0.10 \mathrm{~g} \mathrm{~g}^{-1} \mathrm{~min}^{-1}$ for $\mathrm{IR}_{60}$ and $0.10 \mathrm{~g} \mathrm{~g}^{-1} \mathrm{~min}^{-1}, 0.04 \mathrm{~g} \mathrm{~g}^{-1} \mathrm{~min}^{-1}$ and $0.014 \mathrm{~g} \mathrm{~g}^{-1} \mathrm{~min}^{-1}$ for $\mathrm{C}_{60}, \mathrm{C}_{50}$, and $\mathrm{C}_{40}$, respectively. In all cases, the transition between constant rate and falling rate periods occurred in the range of $60-75 \%$ moisture content. As expected shorter drying times were found at higher drying temperatures (Daud \& Armstrong, 1988; Moraes et al., 2014; Moreira et al., 2011; Reis et al., 2013). The drying time was 120 min for $I_{60}$ drying method, and 580, 240 and 120 min for $C_{40}, C_{50}$, and $C_{60}$ conduction drying method respectively. This drying time is much shorter than the normally used for films prepared by casting (Denavi \& PerezMateos et al., 2009; Denavi \& Tapia-Blácido et al., 2009; Moraes et al., 2013).

\subsection{Effect of drying conditions on film properties}

Regardless of the temperature used, the films dried by conduction presented similar thickness ( $\cong 105 \mu \mathrm{m}$ ). In contrast the films dried by IR radiation were thicker (Table 3), implying a lower degree of compaction of the protein matrix probably due to a different degree of molecular unfolding or cross-linking within the protein network of the film. Both the drying mechanism and temperature modified protein conformation and determined fundamentally the ability of protein chains to interact with each other as well as with other components of the formulation under consideration during film formation. The type and number of interactions involved in the stabilization of a protein matrix (disulphide covalent bonds, hydrogen bonding, electrostatic attractions, and hydrophobic bonding) would determine the degree of crosslinking and the hydrophylic-hydrophobic character of the films and also correlate with the latter's physicochemical, mechanical, and barrier properties (Denavi \& Perez-Mateos et al., 2009; Denavi \& Tapia-Blácido et al., 2009).

All the films were homogeneous and had the yellow hue typically observed in soy protein biopolymers (González, Strumia, \& Alvarez Igarzabal, 2011; Song, Tang, Wang, \& Wang, 2011). No differences among color parameters $\left(L^{*}, a^{*}, b^{*}\right.$ and $\left.\Delta E\right)$ were observed among films (Table 3). Denavi and Perez-Mateos et al. (2009); Denavi and Tapia-Blácido et al. (2009) also reported that the drying

Table 3

Thickness, color ( $\left.\mathrm{L}^{*}, \mathrm{a}^{*}, \mathrm{~b}^{*}, \Delta \mathrm{E}\right)$, and opacity of SPI films processed by tape casting and dried at 40,50 and $60{ }^{\circ} \mathrm{C}$ by conduction or at $60{ }^{\circ} \mathrm{C}$ by IR radiation.

\begin{tabular}{|c|c|c|c|c|c|c|}
\hline \multirow[t]{2}{*}{ Sample } & \multirow[t]{2}{*}{ Thickness $(\mu \mathrm{m})$} & \multicolumn{4}{|c|}{ Hunter-lab color parameters } & \multirow[t]{2}{*}{ Opacity (UA/mm) } \\
\hline & & $\mathrm{L}^{*}$ & $a^{*}$ & $b^{*}$ & $\Delta \mathrm{E}$ & \\
\hline $\mathrm{C}_{40}$ & $105.8 \pm 17.3 \mathbf{b}$ & $84.5 \pm 1.4 \mathbf{a}$ & $-1.8 \pm 0.3 \mathbf{a}$ & $31.2 \pm 3.1 \mathbf{a}$ & $32.2 \pm 3.3 \mathbf{a}$ & $1.5 \pm 0.05 \mathbf{a}$ \\
\hline$C_{50}$ & $107.8 \pm 12.5 \mathbf{b}$ & $86.1 \pm 0.5 \mathbf{a}$ & $-2.2 \pm 0.1 \mathbf{a}$ & $29.6 \pm 0.9 \mathbf{a}$ & $30.1 \pm 1.0 \mathbf{a}$ & $1.0 \pm 0.05 \mathbf{b}$ \\
\hline $\mathrm{C}_{60}$ & $104.2 \pm 14.6 \mathbf{b}$ & $86.1 \pm 2.0 \mathbf{a}$ & $-2.1 \pm 0.4 \mathbf{a}$ & $28.0 \pm 2.6 \mathbf{a}$ & $28.7 \pm 3.0 \mathbf{a}$ & $1.1 \pm 0.01 \mathbf{b}$ \\
\hline $\mathrm{IR}_{60}$ & $185.3 \pm 31.4 \mathbf{a}$ & $85.4 \pm 3.3 \mathbf{a}$ & $-1.9 \pm 0.7 \mathbf{a}$ & $30.7 \pm 5.4 \mathbf{a}$ & $31.4 \pm 6.1 \mathbf{a}$ & $0.6 \pm 0.02 \mathbf{c}$ \\
\hline
\end{tabular}

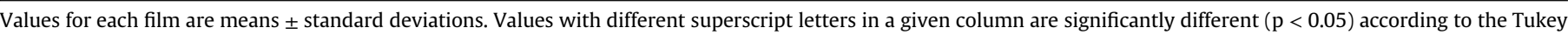
test. 
Table 4

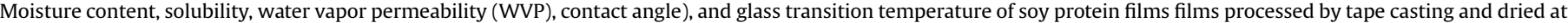
40,50 and $60{ }^{\circ} \mathrm{C}$ by conduction or at $60{ }^{\circ} \mathrm{C}$ by IR radiation.

\begin{tabular}{|c|c|c|c|c|c|}
\hline Sample & Moisture content (\%) & Solubility (\%) & $\mathrm{WVP} \times 10^{-10}(\mathrm{~g} / \mathrm{m}$ Pa s$)$ & Contact angle $\left(^{\circ}\right)$ & $\operatorname{Tg}\left({ }^{\circ} \mathrm{C}\right) \mathrm{DSC}$ \\
\hline $\mathrm{C}_{40}$ & $12.04 \pm 0.51 \mathbf{a}$ & $33.70 \pm 0.01 \mathbf{a}$ & $1.32 \pm 0.19 \mathbf{a}$ & $75.13 \pm 4.40 \mathbf{a}$ & $-20.8 \pm 0.8 \mathbf{b}$ \\
\hline $\mathrm{C}_{50}$ & $12.79 \pm 0.19 \mathbf{a}$ & $33.62 \pm 2.42 \mathbf{a}$ & $1.47 \pm 0.33 \mathbf{a}$ & $67.66 \pm 7.41 \mathbf{a b}$ & $-21.1 \pm 0.5 \mathbf{b}$ \\
\hline $\mathrm{C}_{60}$ & $12.15 \pm 0.12 \mathbf{a}$ & $31.23 \pm 1.28 \mathbf{a}$ & $0.95 \pm 0.21 \mathbf{a}$ & $56.07 \pm 5.33 \mathbf{b}$ & $-16.5 \pm 0.7 \mathbf{a}$ \\
\hline $\mathrm{IR}_{60}$ & $12.25 \pm 0.22 \mathbf{a}$ & $32.69 \pm 1.91 \mathbf{a}$ & $1.61 \pm 0.68 \mathbf{a}$ & $66.03 \pm 5.80 \mathbf{a b}$ & $-19.8 \pm 0.3 \mathbf{b}$ \\
\hline
\end{tabular}

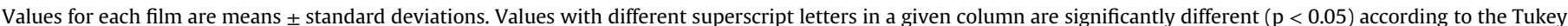
test.

conditions of soy protein films prepared by casting did not affect color. However, the opacity of the films decreased at higher drying temperatures (Table 3), which could be due to extensive protein cross-linking. The mechanisms determining the differences in opacity and thickness between $\mathrm{C}_{60}$ and $\mathrm{IR}_{60}$ (Table 3 ) is unclear. The differences in the initial drying rate may be critical for the properties of the films (Denavi \& Perez-Mateos et al., 2009; Denavi \& Tapia-Blácido et al., 2009; Reis et al., 2013; Salgado et al., 2016). The location of the heating medium in the lower film surface in conduction drying could have also favored the formation of microbubbles, which may in turn affect the film transparency. Further, work is needed to address that.

Table 4 shows the moisture content, solubility, water vapor permeability (WVP), contact angle $\left(^{\circ}\right.$ ) and glass transition temperature of the films processed by tape casting under different conditions. Hydrophilic properties of the films were not influenced by drying method and temperature. This is in agreement with Denavi and Perez-Mateos et al. (2009); Denavi and Tapia-Blácido et al. (2009) who did not find differences in these properties either in soy proteins films processed by casting and dried at different temperatures and relative humidity. The WVP values obtained are in the range of those published for soy protein films obtained by casting (Denavi \& Perez-Mateos et al., 2009; Denavi \& TapiaBlácido et al., 2009; Salgado et al., 2011) without the dependence on this property with film thickness that has been reported for hydrophilic films (Ghorpade, Li, Gennadios, \& Hanna, 1995; McHugh, Avena-Bustillos, \& Krochta, 1993).

The contact angles values suggest that the drying method influenced film's surface energy. Increasing the drying temperature by conduction resulted in lower surface hydrophophicity (lower contact angles) (Table 4). Moreover, the films dried by IR radiation presented higher surface hydrophobicity than those obtained by conduction drying at the same temperature $\left(60^{\circ} \mathrm{C}\right)$. Even though the kinetics of drying by $\mathrm{IR}_{60}$ and by $\mathrm{C}_{60}$ did not show differences, in the former the heat was delivered from the top to the bottom of the film, while in the latter the heat was delivered in the opposite direction. These facts could explain differences in the films surface. During drying, water is progressively eliminated, changing proteins conformation and the interactions that can be established among protein chains (Denavi \& Perez-Mateos et al., 2009; Denavi \& Tapia-Blácido et al., 2009). It is worth noting that the conformational changes that may contribute to explain the modification in film's surface hydrophobicity did not affect water content and WVP.

The films dried at $60^{\circ} \mathrm{C}$ by conduction presented higher tensile strength and Young modulus and lower elongation at break than films dried 40 and $50{ }^{\circ} \mathrm{C}$ or dried by IR radiation at $60{ }^{\circ} \mathrm{C}$ (Fig. 4). Previous studies have shown that disulfide bridges are favored at high pHs and temperatures, presenting a major role in the stabilization of soy proteins, which in turn influence the mechanical properties (Mauri \& Añón, 2006; Salgado et al., 2010). Denavi and Perez-Mateos et al. (2009); Denavi and Tapia-Blácido et al. (2009) reported that higher drying temperatures increased the tensile strength of soy protein films prepared by casting. However, in this case higher elongation values were also found. This suggests that the processing method may affect the level protein interactions within the film matrix. Further studies may be conducted to

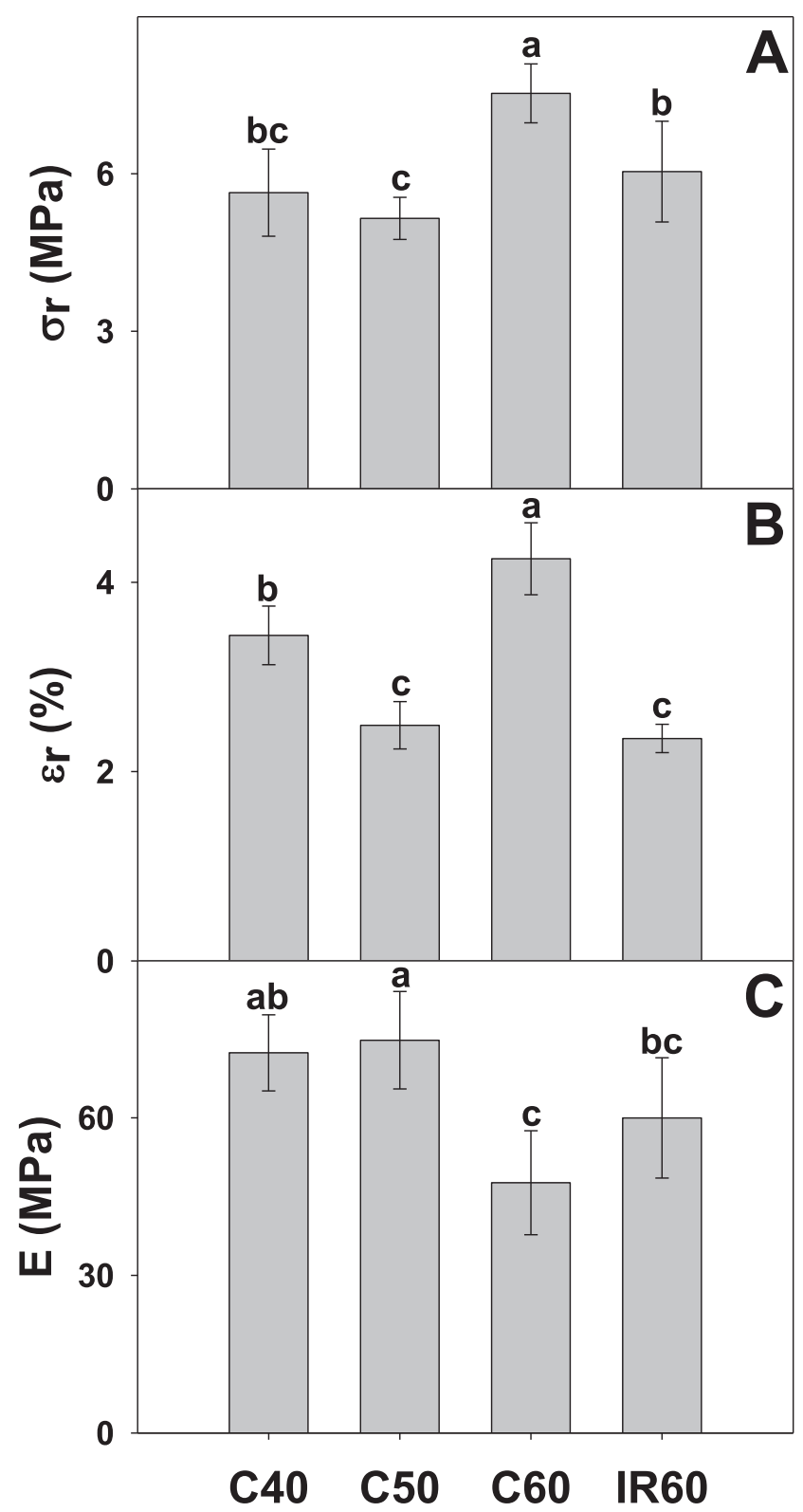

Fig. 4. Tensile strength (A), Young's modulus (B) and elongation at break (C) of films processed by tape casting, dried at 40,50 and $60{ }^{\circ} \mathrm{C}(\mathrm{C} 40, \mathrm{C} 50, \mathrm{C} 60)$ by conduction and at $60{ }^{\circ} \mathrm{C}$ by IR radiation (IR60). Error bars are shown. Different letters indicated significant differences based on Tukey test at a level of significance of $\mathrm{P} \leq 0.05$. 


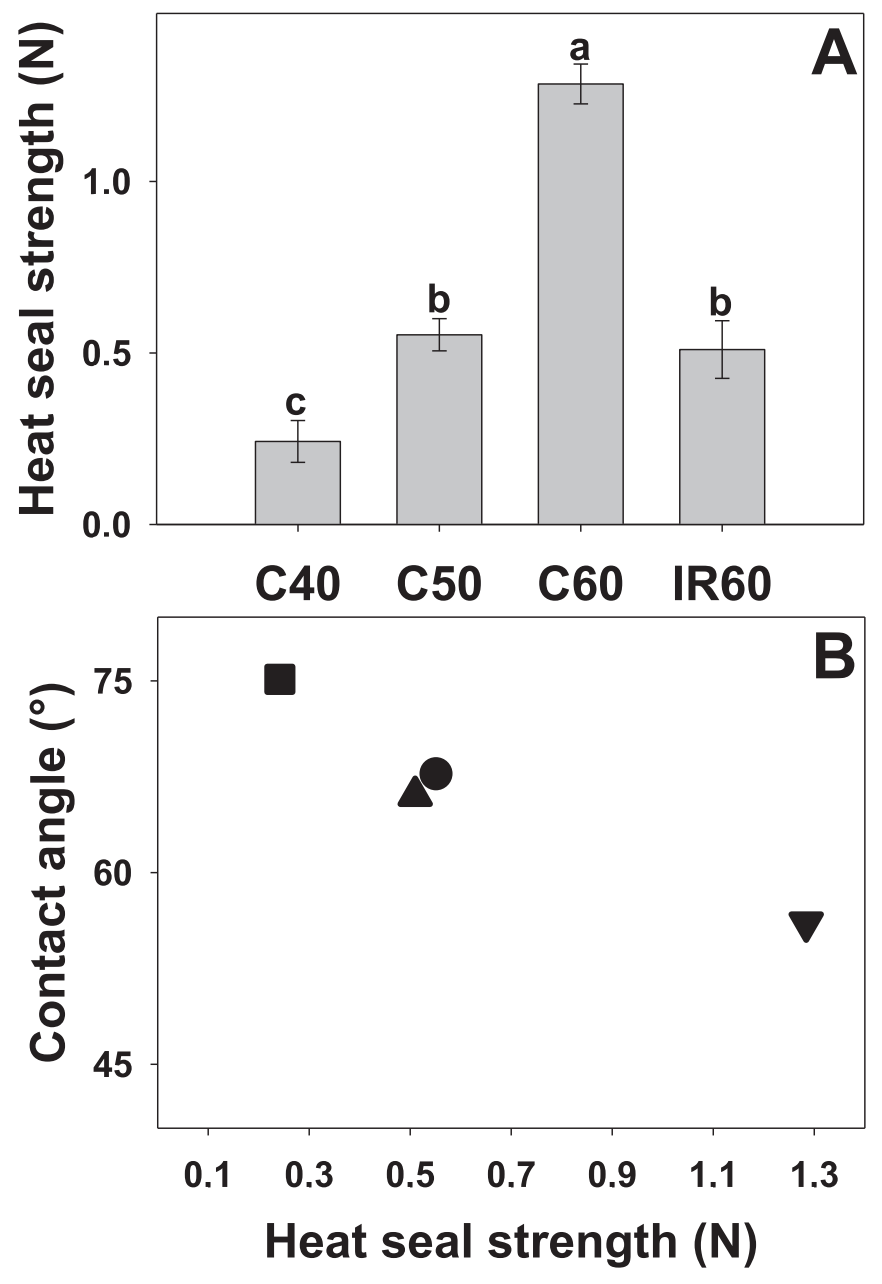

Fig. 5. Heat sealing resistance of films processed by tape casting, dried at 40,50 and $60{ }^{\circ} \mathrm{C}(\mathrm{C} 40, \mathrm{C} 50, \mathrm{C} 60)$ by conduction and at $60^{\circ} \mathrm{C}$ by IR radiation (IR60) (A). Error bars are shown. Different letters indicated significant differences based on Tukey test at a level of significance of $\mathrm{P} \leq 0.05$. Association between the heat seal strength and the contact angle of films processed by tape casting and dried at $(\boldsymbol{\square}) 40,(\boldsymbol{O}) 50$ and $(\boldsymbol{\nabla})$ $60{ }^{\circ} \mathrm{C}$ by conduction or $(\boldsymbol{A})$ IR radiation $(\mathbf{B})$.

determine the degree of protein interactions in the different films, as affected by the drying conditions and methods. The potential increase of protein crosslinking in $\mathrm{C}_{60}$ films, which may have contributed to improve the mechanical properties, was in line with the higher glass transition temperature presented by this sample (Table 4).

All the films were able to produce continuous thermo-seals, which may be appealing for certain technological uses (Scheibe, De Moraes, \& Laurindo, 2014). Higher drying temperatures resulted in films with improved thermo-seal resistance. Conduction drying yielded films with higher thermos-seal resistance than IR radiation drying. Noteworthy, there was a negative correlation between the film contact angle and thermo-seal resistance (Fig. 5). The facts that in all cases the seal failure was adhesive suggest a major role of film's surface on the thermos-seal resistance. However, thermo-sealing processes are affected by several factors that may exceed the film surface.

\section{Conclusions}

Results from this study demonstrate that soy proteins-based films can be produced by tape casting in large scale. The film- forming suspension should have the minimal protein concentration of $10.5 \% \mathrm{w} / \mathrm{v}$ to allow its correct application on the support. The drying conditions (heat transfer method and temperature) have great impact on the physical properties of the resulting films. Drying at $60^{\circ} \mathrm{C}$ not only reduced the drying time, but also yielded in films with superior mechanical properties and heat seal strength than films dried at lower temperatures. Although a similar drying time was observed for $I_{60}$, these films had poorer mechanical properties than those dried by conduction.

In the tape taping process, a solution or suspension is spread onto a flat plate, heated with hot water circulating in a reservoir, which supplies the heat required by the drying process. One advantage of this drying method is the possibility of producing larger films in short times, when compared to the casting procedure, which result in films with no more than $30 \mathrm{~cm}$. Tape casting uses relatively low drying temperature and short drying times, resulting in films with good mechanical properties. The use of infrared heating is an alternative to improve drying, when associated with heat conduction from the hot plate. Therefore, tape casting is a suitable process to produce films at industrial scale. Though further work is needed to determine the changes in protein structure and interaction in response to different drying treatments, the information presented herein may be useful for projects aiming to scale up the production of custom-designed protein films.

\section{Acknowledgements}

The authors would like to thank the Argentine National Research Council (CONICET), Argentine the National Agency of Scientific and Technological Support (ANPCyT, PICT-2010-1837, PICT-2013-2124), La Plata National University (UNLP, Project 11/ X618 and 11/X750), Santa Catarina Foundation for Research (FAPESC, Brazil) and CYTED (Project 309AC0382) for financial support.

\section{Appendix A. Supplementary data}

Supplementary data related to this article can be found at http:// dx.doi.org/10.1016/j.foodhyd.2016.12.029.

\section{References}

ASTM D644-94. (1994). Standard test methods for moisture content of paper and paperboard by oven drying. In Annual Book of ASTM Standards. American Society for Testing Materials, Philadelphia, PA, USA. págs. 1-2.

ASTM D882-02 (2004). Standard test method for tensile properties of thin plastic sheeting. In Annual book of ASTM standards. Philadelphia, PA, USA: American Society for Testing and Materials.

ASTM E96-80. (1989). Standard test methods for water vapor transmission of materials. In . Vol 15. Anmual book of ASTM Standards (pp. 745-754). Philadelphia, PA, USA: American Society for Testing Materials.

ASTM F88-00. (2004). Standard test method for seal strength of flexible barrier materials. In Annual book of ASTM Standards. Philadelphia, PA, USA: American Society for Testing Materials.

Bradford, M. M. (1976). A Rapid and Sensitive Method for the Quantitation of Microgram Quantities of Protein Utilizing the Principle of Protein-Dye Binding. Analytical Biochemistry, 72, 248-254.

Condés, M. C., Añón, M. C., Mauri, A. N., \& Dufresne, A. (2015). Amaranth protein films reinforced with maize starch nanocrystals. Food Hydrocolloids, 47 $146-157$.

Cuq, B., Gontard, N., \& Guilbert, N. (1998). Proteins as agricultural polymers for packaging production. Cereal Chemistry Journal, 75, 1-9.

Daud, W. R. W., \& Armstrong, W. D. (1988). Conductive drying characteristics of gelatinized rice starch. Drying Technology, 6, 655-674.

Denavi, G., Perez-Mateos, M., Añón, M. C., Montero, P., Mauri, A. N., \& GómezGuillén, M. C. (2009). Structural and functional properties of soy protein isolate and cod gelatin blend films. Food Hydrocolloids, 23, 2094-2101.

Denavi, G. Tapia-Blácido, D. R. Añón, M. C. Sobral, P. J. A., Mauri, A. N., \& Menegalli, F. C. (2009). Effects of drying conditions on some physical properties of soy protein films. Journal of Food Engineering, 90, 341-349. 
Echeverria, I., Eisenberg, P., \& Mauri, A. N. (2014). Nanocomposites films based on soy proteins and montmorillonite processed by casting. Journal of Membrane Science, 449, 15-26.

Foulk, J. A., \& Bunn, J. M. (2001). Properties of compression-molded, acetylated soy protein films. Industrial Crops and Products, 14(1), 11-22.

Gennadios, A., Weller, C. L., \& Gooding, C. H. (1994). Measurement errors in water vapor permeability of highly permeable, hydrophilic edible films. Journal of Food Engineering, 21, 395-409.

Ghorpade, V. M., Li, H., Gennadios, A., \& Hanna, M. A. (1995). Chemically modified soy protein films. Trans. ASAE, 38(6), 1805-1808.

Gontard, N., Guilbert, S., \& Cuq, J. L. (1992). Edible wheat gluten films: Influence of the main process variables on film properties using response surface methodology. Journal of Food Science, 57, 190-195.

González, A., Strumia, M. C., \& Alvarez Igarzabal, C. I. (2011). Cross-linked soy protein as material for biodegradable films: Synthesis, characterization and biodegradation. Journal of Food Engineering, 106, 331-338.

Guilbert, S., \& Cuq, B. (2005). Chapter 11: Material formed from proteins. In C. Bastioli (Ed.), Handbook of biodegradable polymers (pp. 339-384). Shawbury, Shrewsbury, Shropshire, Inglaterra: Smithers: Rapra Technology Limited.

Han, J. Shin, S.-H., Park, K.-M., \& Kim, K. M. (2015). Characterization of physical, mechanical, and antioxidant properties of soy protein-based bioplastic films containing carboxymethylcellulose and catechin. Food Science and Biotechnology, 24, 939-945.

Lafargue, D., Lourdin, D., \& Doublier, J.-L. (2007). Film-forming properties of a modified starch/K-carrageenan mixture in relation to its rheological behavior: Carbohydrate Polymers, 70, 101-111.

Mauri, A. N., \& Añón, M. C. (2006). Effect of solution pH on solubility and some structural properties of soybean protein isolate films. Journal of the Science of Food and Agriculture, 86(7), 1064-1072.

Mauri, A. N., \& Añón, M. C. (2008). Mechanical and physical properties of soy protein films with $\mathrm{pH}$ modified microstructures. Food Science and Technology International, 14, 119-125.

Mauri, A. N., \& Añón, M. C. (2012). Películas y recubrimientos comestibles: Propiedades y aplicaciones en alimentos. In G. I. Olivas, R. Soliva-Fortuni, O. MartínBelloso, \& G. González-Aguilar (Eds.), Editorial Clave, México. Chapter 4: Proteínas como envases alimentarios (p. 95).

McHugh, H. T. Avena-Bustillos, R. \& Krochta, J. M. (1993). Hydrophilic edible films: Modified procedure for water vapor permeability and explanation of thickness effects. Journal of the Science of Food and Agriculture, 58, 899-903.

Moraes, J. O., Reszka, A., \& Laurindo, J. B. (2014). Espalhamento e secagem de filme de amido glicerol fibra preparado por tape casting. Pesquisa Agropecuaria Brasileira, 49, 136-143.

Moraes, J. O., Scheibe, A. S., Augusto, B., Carciofi, M., \& Laurindo, J. B. (2015) Conductive drying of starch-fiber films prepared by tape casting:drying rates and film properties. LWT - Food Science and Technology, 64, 356-366.

Moraes, J. O., Scheibe, A. S., Sereno, A., \& Laurindo, J. B. (2013). Scale-up of the production of cassava starch based films using tape-casting. Journal Food Engineering, 119, 800-808.
Moreira, R., Chenlo, F., Torres, M. D., Silva, C., Prieto, D. M., Sousa, A. M. M., et al. (2011). Drying kinetics of biofilms obtained from chestnut starch and carrageenan with and without glycerol. Drying Technology: An International Journal, 29, 1058-1065.

Ramos, Ó. L., Fernandes, J. C., Silva, S. I., Pintado, M. E., \& Malcata, F. X. (2012). Edible films and coatings from whey proteins: A review on formulation, and on mechanical and bioactive properties. Critical Reviews in Food Science and Nutrition, 52, 533-552.

Reis, R. C., Correa, P. C., Devilla, I. A., Santos, E. S., Ascheri, D. P. R., Servulo, A. C. O., et al. (2013). Drying of yam starch (Dioscorea ssp.) and glycerol filmogenic solutions at different temperatures. LWT - Food Science and Technology, 50, $651-656$.

Richard, M. E., \& Twiname, E. R. (2000). Tape casting: Theory and practice. USA: American Ceramics Society.

Salgado, P., Fernández, G., Drago, S., \& Mauri, A. (2011). Addition of bovine plasma hydrolysates improves the antioxidant properties of soybean and sunflower protein-based films. Food Hydrocolloids, 25, 1433-1440.

Salgado, P. R., Molina Ortiz, S. E., Denavi, G. A., Bosch, M. A., Añón, M. C., \& Mauri, A. N. (2016). Influence of initial protein structure on the properties of soybean protein edible films. In V. K. Thakur, M. K. Thakur, \& M. R. Kessler (Eds.), Soy-based bioplastics. UK: Smithers Rapra Publisher (in press).

Salgado, P. R., Molina Ortiz, S. E., Petruccelli, S., \& Mauri, A. N. (2010). Biodegradable sunflower protein films naturally activated with antioxidant compounds. Food Hydrocolloids, 24, 525-533.

Scheibe, A. S., De Moraes, J. O., \& Laurindo, J. B. (2014). Production and characterization of bags from biocomposite films of starch-vegetal fibers prepared by tape casting. Journal Food Process Engineering, 37(5), 482-492.

Song, F., Tang, D.-L., Wang, X.-L., \& Wang, Y.-Z. (2011). Biodegradable soy protein isolate-based materials: A review. Biomacromolecules, 12, 3369-3380.

Steffe, I. F. (1996). Rheological methods in foods processing engineering (2nd ed.). Michigan: Freeman Press.

Tanimoto, Y., Hayakawa, T., \& Nemoto, K. (2005). Tape-casting technique can prepare beta-TCP sheets with uniform thickness and flexibility. Journal of Biomedical Materials Research Part B: Applied Biomaterials, 73, 157-163.

Tapia-Blácido, D. R., do Amaral Sobral, P. J., \& Menegalli, F. C. (2013). Effect of drying conditions and plasticizer type on some physical and mechanical properties of amaranth flour films. LWT - Food Science and Technology, 50, 392-400.

Tapia-Blácido, D., Sobral, P. J., \& Menegalli, F. C. (2005). Development and characterization of biofilms based on Amaranth flour (Amaranthus caudatus). Journal of Food Engineering, 67, 215-223.

Wittaya, T. (2012). Protein-based edible films: Characteristics and Iimprovement of properties, structure and function of food engineering. In A. Amer Eissa (Ed.), InTech. http://dx.doi.org/10.5772/48167. Available from: http://www. intechopen.com/books/structure-and-function-of-food-engineering/proteinbased-edible-films-characteristics-and-improvement-of-properties.

Zotarelli, M. F., Carciofi, B. A. M., \& Laurindo, J. B. (2015). Effect of process variables on the drying rate of mango pulp by refractance window. Food Research International, 69, 410-417. 